blocks about 10 inches long. Thus I get from six to 10 houses from one tree. A notch an inch and a half wide and an inch and half deep is cut out at one end; when a board is nailed over this end, this becomes the entrance hole. Two drainage holes are drilled in the board applied over the other end, and this forms the floor.

The houses are placed at least 300 vards apart, on poles five or six feet from the ground. The entrance holes face east or south, away from prevailing winds. Each house is wired to the post, and further secured by two nails driven obliquely through the back of the house into the post.

This summer I have put up another 50 houses, so that 200 will be in readiness for next spring. I have a record of each house, including its location, the species using it, number of eggs, number of young raised, complete with the date of its erection and each occurrence thereafter.

I am still waiting for Purple Mar- tins. Last winter I built a 28-room martin house, which I placed on the windmill in our yard. Purple Martins visited it off and on throughout June but did not stay to nest. I hope they will take up residence next year.

\section{EASTERN BLUEBIRDS}

by David N. Ashdown, Okla

A pair of Eastern Bluebirds nested this year (1966) at Okla, 40 miles northwest of Yorkton. Their home was a bird box of rough lumber placed in an aspen poplar at the edge of a pasture three miles south of the town. The nest was found on June 6 , and observed to have two eggs on June 10 and five eggs on June 13. It was visited by Dr. Stuart Houston on June 20 when the female was lifted from the nest box and banded. The five young were raised successfully and were last seen on July 13. Nearby a Mountain Bluebird successfully raised six young, these birds being only a few days old at the time of Dr. Houston's visit on June 20.

\title{
AFTER 50 YEARS, THE EASTERN BLUEBIRD NESTS AGAIN AT REGINA
}

\author{
by Margaret Belcher, 2601 Winnipeg St., Regina
}

Fifty years ago people who talked about bluebirds in Regina appear to have meant Eastern Bluebirds. At least, the bluebird that Mitchell saw raising two broods in Regina in 1916 is known to have been of this species (Belcher, 1961). On the other hand, for the 20 years that I have been in Regina, our bluebirds have been Mountain Bluebirds, seen commonly in migration and nesting just beyond the Regina area as one goes north to the Qu'Appelle Valley through country sprinkled with aspen groves. Indeed, we have come to recognize the Mountain Bluebird as the common breeding bluebird of Saskatchewan and to think of the Eastern Bluebird as rare, except for occasional observations in spring and fall migration. Obviously some changes have taken place over the years in the status of these birds, and it is interesting to go back to early accounts to see whether we can trace any pattern of occurrence.

Mitchell (1924) described the Eastern Bluebird (Siala sialis) as a "fairly common summer visitant locally through transition zone, found breeding in Cypress Hills and Moose Mountain and northward to Hudson Bay Junction." There is no suggestion in this statement that the Eastern Bluebird was to be expected only in the eastern part of the province, and he further comments in reference to the Mountain Bluebird that the range of the two species overlaps.

Further particulars of the Cypress Hills records referred to by Mitchell are supplied by Godfrey (1950) who tells that Laurence Potter had a pair breeding at Eastend in 1922 and reported the appearance of an additional pair in 1923 that did not nest. In 1943, however, Potter wrote that the bird was then an irregular and un- 


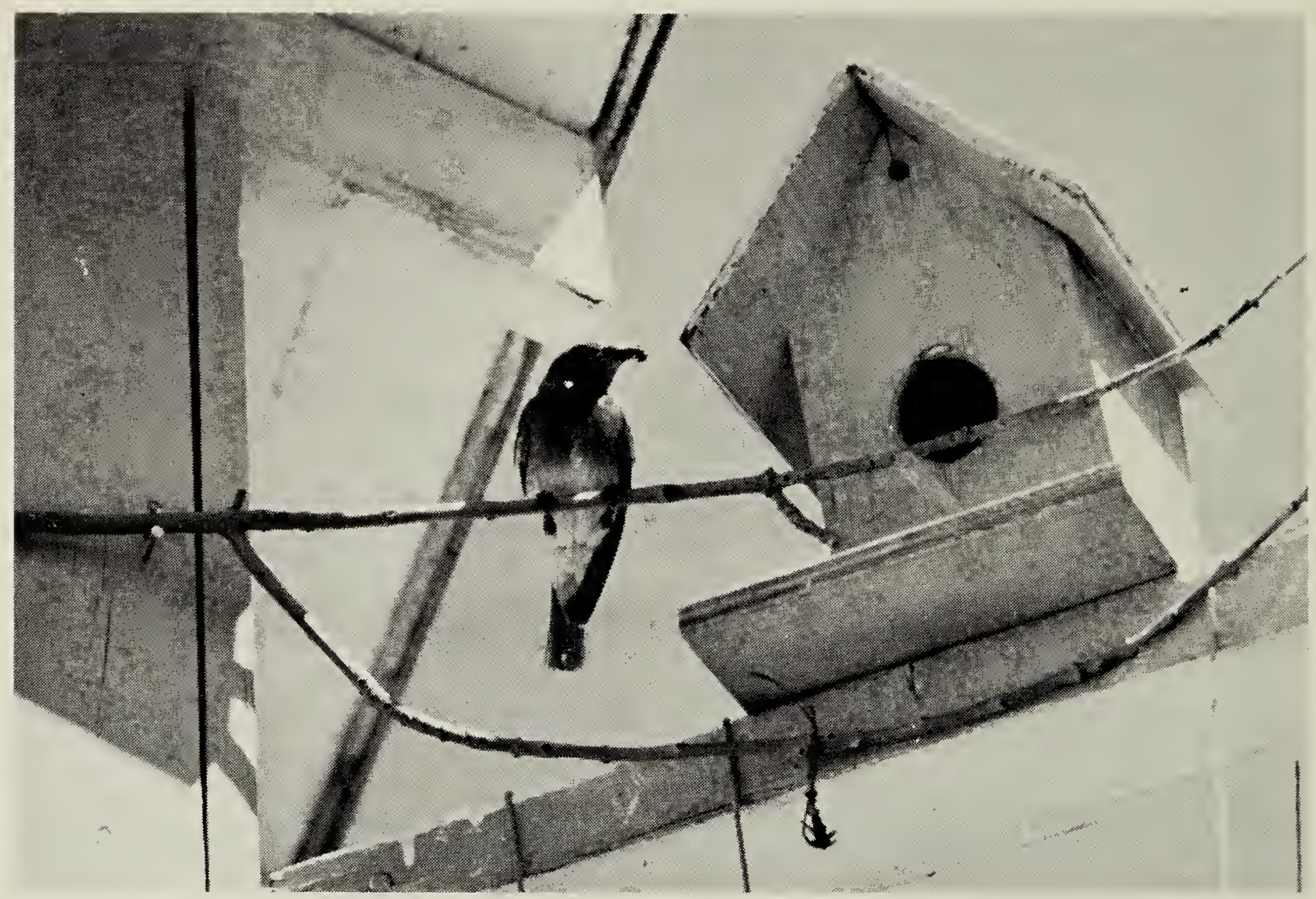

Photo by Arnold Foster

Male Eastern Bluebird at nest box in Regina, August 1, 1966

common visitant. Godfrey found it significant that Bent had not recorded the species in his 1907 expedition into southwestern Saskatchewan, reported in 1908, nor had Taverner and Laing recorded it in 1921. It is possible that Potter's observations mark the first appearance of the Eastern Bluebird so far west, for Bent writing in 1949 states: "The eastern bluebird has extended its range westward within a generation or two. At Portage la Prairie, Manitoba, in 1884 it was referred to as a 'recent arrival'. In 1909, Macoun did not mention any occurrence of this species in Saskatchewan; in 1922 it was found breeding in the Cypress Hills of southwestern Saskatchewan." In 1948, from one to five birds were seen in the proximity of ranch houses on the north slope of the lower Cypress Hills by Godfrey's party during the month of June, indicating that the species was still being recorded in that area. In the adjacent Maple Creek ranching country, Steve Mann of Piapot recorded an Eastern Bluebird on April 27 of this year (1966); this was only his third observation of the species in the many years that he has kept records in this area.

Bent's conclusions with respect to the first occurrence of the Eastern Bluebird in Saskatchewan are further borne out by an historical study of the bird species in the Qu'Appelle Valley now being made by Manley Callin. Callin has found that early observers who visited or lived in the area from 1858 to 1896 did not record either species of bluebird. However, in 1907 and 1909 George Lang recorded the Eastern Bluebird as a transient at Indian Head, and in 1929 he described it as a rare nester. Through the 1930's and 1940's the Eastern Bluebird continued to be regarded as a regular, but uncommon, summer resident in the eastern section of the Qu'Appelle Valley region being studied by Callin, but in this same area from 1949 to 1962 only one record was reported, and farther west in the valley bottom at Fort Qu'Appelle Callin has never seen the species in 23 years of observations from 1943 to 1966 .

The record of a nest with four eggs found June 14, 1923 at Hudson Bay 
Junction (Sask. Museum of Natural History files) justifies Mitchell's inclusion of this locality in the breeding range of the Eastern Bluebird, and on the strength of this record the species was to be expected in central as well as in southern Saskatchewan. In the Yorkton district, Houston (1949) reported it as "rather uncommon; no nesting records as yet." At Nipawin it is considered a "rare straggler" (Houston and Street, 1959) and one was seen by C. Stuart Francis on his farm at Torch River, May 21, 1957. One was reported seen at Roddick, May 21 to June 22, 1927 by Bard and Mitchell and one southeast of the city of Prince Albert about 1934 or 1935 (Houston and Street, 1959). North of the city of Prince Albert, on the north side of Emma Lake, Fred Bard saw one bird on August 2, 1932 (Sask. Museum of Natural History files). At Tullis, west of the South Saskatchewan River, Roy (1964) saw a family of five during the entire late summer and fall of 1938. Much farther north, in the Lake Athabasca region, the bird is on the hypothetical list, for a bluebird seen there by Dr. J. Beatty in the fall of 1959 is believed to have been an Eastern Bluebird (Nero, 1963).

These representative studies seem to indicate a somewhat erratic occurrence of the bird in Saskatchewan rather than any definite pattern of increase and decline in population, or even any gradual and persistent extension of range. It is perhaps in this context that it is best to see the 1966 nesting records from Okla (southeast of Kelvington), Indian Head and Regina. Furthermore, it is not clear from these studies whether the movement of the Eastern Bluebird into Saskatchewan is principally from the east, or whether it may come in part from the south. We know of breeding populations to the south and southwest, the A.O.U. Check-list (1957) reporting that the species "breeds from southern Saskatchewan (Cypress Hills, Eastend, Davidson) ... along the eastern foothills of the Rockies in Montana (Great Falls, Billings) . . . more commonly through the Dakotas ...."

In any case, some excitement was occasioned this summer in Regina by the first nesting of the Eastern Bluebird in the city in 50 years. The breeding pair was first seen at the home of Arnold Foster about July 7, and the Fosters' tentative identification of them as Eastern Bluebirds was confirmed by Vic Schmidt of the Saskatchewan Museum of Natural History on July 26, by which time young - probably a few days old were found to be in the nest. Notes kept by the son, Stephen Foster, record that the birds were seen frequently feeding their young from July 30 to August 5, during which time the adults were photographed by $\mathrm{Mr}$. Foster and members of the Museum staff. On August 9 the first young were seen out of the nest attempting to fly, and on August 12 the birds were seen for the last time. The birds nested in a brightly painted green and yellow bird house mounted some six feet above the ground along a wall bordered by a path that was frequently used, and did not seem to be at all disturbed by people.

Mr. Foster wondered if the bluebirds which nested in their yard in July were raising their second brood, and this is entirely possible. In connection with this breeding record it is of interest to note that we have what appears to be a record early arrival date for this species in the Regina area this year, for three Eastern Bluebirds were seen on March 30 by W. H. Beck and R. R. Taylor.

\section{LITERATURE CITED}

American Ornithologists' Union. 1957. Checklist of North American birds. Fifth ed., Baltimore. $691 \mathrm{p}$.

Belcher, M. 1961. Birds of Regina. Special Publ. No. 3, Sask. Nat. Hist. Soc., Regina. $76 \mathrm{p}$.

Bent, A. C. 1949. Life histories of North Amercan thrushes, kinglets, and their allies. U.S. Nat. Mus. Bull. 196. 454 p.

Godfrey, W. E. 1950. Birds of the Cypress Hills and Flotten Lake regions, Saskatchewan. Nat. Mus. of Can., Bull. No. 120 , Ottawa. $96 \mathrm{p}$.

Houston, C. S. 1949. The birds of the Yorkton district, Saskatchewan. Can. Field-Nat. 63: 215-41.

Houston, C. S., and M. G. Street. 1959. The birds of the Saskatchewan River, Carlton to Cumberland. Sask. Nat. Hist. Soc., Spec. Publ. No. 2, Regina. 205 p.

Mitchell, H. H. 1924. Birds of Saskatchewan. Can. Field-Nat., $38: 101-118$.

Nero, R. W. 1963. Birds of the Lake Athabasca region, Saskatchewan. Sask. Nat. Hist. Soc., Spec. Publ. No. 5, Regina. 143 p.

Roy, J. F. 1964. Birds of the Elbow. Sask. Nat. Hist. Soc., Regina. 33 p. 